\title{
Meraih Profesionalisme Wartawan
}

\author{
DARAJAT WIBAWA \\ Universitas Islam Negeri SGD Bandung \\ email: darajatwibawa@yahoo.com
}

\begin{abstract}
Since reformation era, the Indonesian mass media had a fundamental change that made Indonesian mediascape and brought Indonesian people becoming the straitmedia society. The journalist had a role as information collector that decided whether the mass media where their work qualified or not. Besides that, it still many things that becoming a problem in journalism and mass media, and one of them is ethical problem. Some questions about the professionalism of the journalist had asked. For answering that questions, the writer tried to research it with descriptive and qualitative approach. Through long interview and observation in 30 journalist in Bandung, the result showed that professionalism could divided into four group that are autonomy, commitment, skill and responsibility. During the implementation of four variations in real activities, it had obstructed lots of problem that interfere journalist duty.
\end{abstract}

Key words: profesionalisme, bandung journalism

\begin{abstract}
Abstrak. Sejak era reformasi, dunia media massa Indonesia mengalami perubahan mendasar. Perubahan tersebut dengan sendirinya mengubah mediascape Indonesia yang membawa masyarakat Indonesia menjadi masyarakat yang sesak-media. Pelaksana pengumpul informasi adalah wartawan. Merekalah yang menentukan berbobot tidaknya media massa tempat mereka bekerja. Namun di balik itu, permasalahan yang menyangkut dunia kewartawanan masih banyak, di antaranya dinilai nyaris tidak beretika dan keluar dari koridor moral. Lantas timbul pertanyaan bagaimanakah pandangan para wartawan sendiri terhadap profesionalisme? Untuk menjawabnya, penulis membedahnya dengan pendekatan deskriptif tradisi kualitatif. Melalui wawancara mendalam dan pengamatan berperanserta kepada 30 wartawan yang bertugas di Kota Bandung dan sekaligus dijadikan informan. Hasilnya menunjukan, profesionalisme bisa dikategorikan ke dalam empat varian yaitu otonomi, komitmen, keahlian dan tanggung jawab. Namun saat hendak menjalankan varian tersebut di lapangan, terganjal aspek-aspek yang turut serta mewarnai saat wartawan bertugas.
\end{abstract}

Kata Kunci: profesionalisme, wartawan bandung

\section{Pendahuluan}

Setelah jatuhnya Orde Baru di bawah kepemimpinan Soeharto, era kebebasan mulai menguak ke permukaan. Kebebasan bukan hanya berpengaruh terhadap satu bidang saja, juga berpengaruh kepada tatanan politik di Indonesia. Sejak era reformasi, pers di Indonesia dapat bernafas lega dalam alam kebebasan. Dunia media massa Indonesia mengalami perubahan mendasar. Bukan hanya dalam jumlah media massa cetak dan elektronik yang bertambah melainkan secara kualitatif juga terjadi perubahan sifat dan keragaman isi media massa.

Dalam era reformasi ini, Indonesia menjadi salah satu negara yang industri media massanya berkembang begitu pesat. Menurut ahli komunikasi dari Universitas Indonesia, Sendjaja, pertumbuhan media massa di Indonesia ditandai tiga hal, yaitu (1) Pengelolaan usaha di bidang media massa tidak lagi dilakukan dalam bentuk yayasan serta semata mengutamakan aspek idealnya, tetapi berupa PT (perseroan terbatas) yang didukung sistem manajemen profesional dan penggunaan produkproduk teknologi canggih serta mengarah kepada komersialisme. (2) Semakin banyaknya para pengusaha nasional atau lazim disebut konglomerat yang menanamkan modalnya di bidang usaha media massa. (3) Media massa yang ada semakin beragam bentuknya dan mengarah pada spesialisasi (Sendjaja, 1993: 118).

Perubahan tersebut dengan sendirinya mengubah mediascape Indonesia yang membawa masyarakat Indonesia menjadi masyarakat yang hidup dalam apa yang diistilahkan sebagai mediasaturated world. Media massa Indonesia sendiri 
mengalami perubahan dari apa yang dinamakan media perjuangan yang penuh dengan nilai idealisme menjadi media komersial yang lebih mengedepankan nilai bisnis. Bahkan menurut Nila Nurlimah, dengan adanya iklim kebebasan pers yang nyaris tanpa batas telah mengakibatkan pers tidak mampu melakukan self censorship terhadap dirinya (Dalam Jurnal Mimbar Vol. XXVII, No. I, Juni 2011: 1).

Pelaksana di lapangan dalam mengumpulkan informasi yang dibutuhkan oleh masyarakat ini adalah barisan wartawan atau reporter. Merekalah yang menentukan berbobot tidaknya media massa tempat mereka bekerja. Tingkat kredibilitas suatu media ada kaitannya dengan kualitas para awak wartawan di lapangan. Perkataan lain, wartawan sebagai salah satu ujung tombak sebuah penerbitan. Bab I mengenai ketentuan umum, UU Pers No. 40 tahun 1999 tentang pers terutama dalam pasal 1 menyebutkan, wartawan adalah orang yang secara teratur melaksanakan kegiatan jurnalistik. Peraturan Rumah Tangga (PRT) pasal 9 Persatuan Wartawan Indonesia (PWI) yang merupakan organisasi wartawan terbesar di Indonesia memperkuat pula definisi wartawan. Menurut peraturan tersebut wartawan adalah orang yang melakukan kegiatan kewartawanan berupa kegiatan/usaha yang berhubungan dengan pengumpulan, pengolahan dan penyiaran dalam bentuk berita, pendapat dan usulan, gambar-gambar dan sebagainya dalam bidang komunikasi massa.

Melalui bahasan yang dirangkai mulai dari huruf, kata dan rangkaian kalimat wartawan mampu merekonstruksi semua aspek kehidupan manusia. Karenanya tidaklah mengherankan jika wartawan bisa dikatakan sebagai agen konstruksi sebuah kenyataan sosial di lapangan. Bukan hanya itu, wartawan tidak semata-mata melaporkan sebuah fakta dan data, wartawan juga turut serta mendefinisikan sebuah peristiwa lalu tanpa disadari secara penuh wartawan mampu membawa pembaca, pemirsa dan para pendengar ke alam pemikiran wartawan bersangkutan Sehingga ungkapan karya sebuah jurnalistik yang disajikan kepada pembaca, pemirsa dan pendengarnya berimplikasi terhadap masalah etika yang dibawa wartawan bersangkutan.

Namun di balik itu, sampai saat ini permasalahan yang menyangkut dunia kewartawanan masih banyak. Menurut Yuniati dan Rachmiatie, wartawan sering terjebak pada good news bad news syndrome. Berita cenderung bersifat dari atas ke bawah (top down) dengan mengutip berbagai pernyataan pejabat pemerintah atau politisi (Jurnal Mimbar, Vol. XXII, No. I, JanuariMaret 2006: 55). Sedangkan dalam sebuah tulisan kolom di Majalah Gatra Edisi 01 Februari 2006, halaman 21 yang berjudul "Wartawan di
Persimpangan Jalan," karya Us Tiarsa, mantan Ketua Persatuan Wartawan Indonesia (PWI) Cabang Jawa Barat, menyebutkan, pers masa kini telah kehilangan rohnya sebagai pejuang pembela rakyat. Pers pasca reformasi nyaris tidak beretika dan keluar dari koridor moral. Menurut Us Tiarsa, caci maki tersebut tidak berhenti di situ saja. Di tengah masyarakat terjadi pemaknaan baru terhadap kemerdekaan pers. Kemerdekaan pers yang diinginkan masyarakat bukan kemerdekaan yang meninggalkan keteraturan.

Namun di sisi lain, wartawan sangat menentukan bagaimana peristiwa sebagai realitas ditampilkan di media massa, yang akhirnya akan membentuk opini masyarakat tentang realitas tersebut walaupun belum tentu persis benar. Pernyataan tersebut seperti yang disampaikan Qodari. Menurut Qodari, wartawan membawa kognisi sosial tertentu ketika memandang suatu persoalan yang akhirnya terpresentasikan dalam bentuk teks yang dapat diamati. Semua persepsi mengenai fenomena berpengaruh terhadap teks yang tercipta (Qodari, 1999:23). Mengingat pentingnya posisi wartawan sebagai wakil dari media massa, maka timbul pertanyaan, bagaimana sebenarnya profesionalisme wartawan? Pertanyaan tersebut ditujukan dan perlu dijawab oleh para wartawan sendiri.

Selama ini, para penulis komunikasi lebih banyak meneliti tentang wartawan atau media massa yang sudah berkembang, maupun yang belum berkembang ditinjau dari pemberitaan, pengaruhnya terhadap masyarakat, atau kecenderungan membandingkan kedua media massa dalam suatu pemberitaan. Bahkan banyak pula meneliti tentang hubungan pendidikan dan pendapatan yang diperoleh wartawan. Sedangkan penelitian yang menyangkut perilaku wartawan yang berkaitan dengan profesionalisme belum banyak dilakukan. Lantas timbul pertanyaan bagaimanakah sebenarnya pandangan para wartawan sendiri terhadap profesionalisme wartawan? Untuk mejawab pertanyaan tersebut, penulis membedahnya dengan metode penelitian deskriptif pendekatan kualitatif.

Pendekatan kualitatif yang dilakukan dalam tulisan ini hakikatnya mengamati orang dalam lingkungan hidupnya, berinteraksi dengan mereka, berusaha memahami bahasa dan tafsiran mereka tentang dunia sekitarnya (Nasution, 1996: 4 dan Garna, 1999:23), dengan demikian pendekatan kualitatif ini hakikatnya mengamati wartawan di Kota Bandung dalam lingkungan hidupnya sendiri. Creswell mendefinikasikan kualitatif sebagai "...an inquiry process of understanding based on distinct methodological traditions of inquiry the explore a social of human problem. The researcher builds a complex, holistic picture, analyzes words, report, detailed, views of informant, and conducts the study in natural setting" Creswell (1998:15). 
Uraian Creswell tersebut memberikan pengertian bahwa pendekatan kualitatif terletak kepada fokus permasalahan yang dikaji. Dengan demikian, segala sesuatu yang berhubungan dengan perilaku wartawan di Kota Bandung ini lebih tepat untuk didekati dengan penelitian kualitatif yang memungkinkan memeroleh data yang lebih dalam dengan mengajukan bukan hanya pertanyaan apa, tetapi mengungkapkan unsur "bagaimana".

Sementara Thomas Lindlof dalam bukunya yang berjudul Qualitative Communication Research Methods, menyatakan, metode kualitatif untuk penelitian komunikasi dengan paradigma fenomenologi, etnometodologi, interaksi simbolik, etnografi, dan studi kultural, sering disebut sebagai paradigma interpretif (Lindolf, 1995: 27-58). Dalam paradigma ini dijelaskan, realitas sosial yang ditunjukkan oleh interaksi sosial yang secara esensial adalah dasar dari komunikasi, bukan saja menampakkan fenomena lambang atau bahasa yang digunakan, tetapi juga menampakkan komunikasi interpersonal di antara anggotaanggota sosial tersebut. Oleh karenanya, komunikasi interpersonal marupakan bagian penting dalam bentuk realitas sosial, "interpersonal communication is the primary medium through which social reality is consctructed" (Lindlof, 1995: 414). Sedangkan teknik pengumpulan data yang penulis lakukan mengikuti saran Creswell yang mengatakan, dalam studi kualitatif terdapat empat teknik pengumpulan data, yaitu Observation (ranging from nonpartisipant to partisipant), interviews (ranging from semistructured to open-ended), document (ranging from private to public), audio visual materials (including materials such as photographs, compact disk and videotapes) (Creswell, 1998:120).

Penulis bukan hanya mengamati saja tetapi ikut bergaul dengan wartawan di Kota Bandung karena pengamatan berperan serta bukan menekankan kepada apa yang dilakukan oleh wartawan melainkan bagiamana wartawan berperilaku. Menurut Mulyana, pengamatan berperan serta menekankan kepada logika penemuan (logic of discovery), suatu proses yang bertujuan menyarankan konsepkonsep atau membangun teori berdasarkan realitas nyata manusia. Lebih jauh Mulyana mengatakan, pengamatan berperan-serta dianggap cocok untuk meneliti bagaimana manusia berperilaku dan memandang realitas kehidupan mereka dalam lingkungan mereka yang biasa, rutin, dan alamiah. Peneliti berusaha memahami makna yang dianut subyek penelitian terhadap perilakunya sendiri dan perilaku orang lain terhadap obyek-obyek dan lingkungannya, misalnya apa yang penting dan tidak penting bagi mereka, dan bagaimana mereka memperlakukan obyek-obyek tersebut (Mulyana, 2003: 167).

Dalam pengamatan berperan-serta ini peneliti ikut berbaur dengan wartawan di Kota
Bandung, ikut menemani mereka ke mana pun kebiasaan mereka pergi berkomunikasi dengan para pejabat tinggi atau dengan orang terkenal lainnya. Cara berkomunikasi dan berinteraksi yang cukup lama dengan subjeknya dalam situasi tertentu memberikan peluang bagi peneliti untuk dapat memandang kebiasaan, konflik, dan perubahan yang terjadi dalam diri subjek dan keterkaitannya dengan lingkungannya. Pengamatan berperan serta ini bisa mengungkap juga mengenai perilaku wartawan yang berada dalam panggung belakang mereka masing-masing. Sedangkan panggung depannya bisa digali melalui wawancara. Karena itu selain observasi berperan serta, pengumpulan data dalam penelitian ini juga dilakukan dengan cara wawancara, yakni kegiatan untuk mendapatkan informasi dengan cara melakukan tanya jawab dengan informan penelitian. Artinya, peneliti melakukan wawancara kepada wartawan di Bandung.

Wawancara menurut Lincoln dan Guba, antara lain mengkonstruksi mengenai orang, kejadian, kegiatan, organisasi, perasaan, motivasi, tuntutan, kepedulian, merekonstruksi masa lalu, memproyeksikan masa depan, memverifikasi, mengubah dan memperluas informasi yang diperoleh dari orang lain (Lincoln dan Guba, 1995). Sementara menurut Patton, terdapat beberapa bentuk atau teknik wawancara, yaitu wawancara pembicaraan informal, wawancara dengan menggunakan petunjuk umum pedoman wawancara, wawancara baku terbuka. Pembagian wawancara Patton ini didasarkan atas perencanaan pertanyaannya (Patton, 1982).

Lebih jauh Mulyana mengemukakan, wawancara secara garis besar dibagi dua yakni wawancara tidak terstruktur dan wawancara terstruktur. Wawancara tidak terstruktur sering juga disebut wawancara mendalam, wawancara intensif, wawancara kualitatif dan wawancara terbuka (openended interview), wawancara etnografis; sedangkan wawancara terstruktur sering juga disebut wawancara baku (standardized interview), yang susunan pertanyaannya sudah ditetapkan sebelumnya (biasanya tertulis) dengan pilihan-pilihan jawaban yang juga sudah disediakan (Mulyana, 2003: 180).

Dalam penelitian ini, peneliti menggunakan wawancara tidak terstruktur, karena saat melakukan wawancara dengan wartawan guna menggali apa yang menjadi pandangan, pemikiran dan kehendak wartawan diperlukan keluwesan, susunan pertanyaannya dan susunan kata-kata dalam setiap pertanyaan dapat berubah saat wawancara, disesuaikan dengan kebutuhan dan kondisi saat wawancara, termasuk karakteristik sosial budaya informan. Meskipun dilakukan wawancara informal namun tetap menggunakan petunjuk umum pedoman wawancara sehingga 
antara satu informan dengan informan yang lain jenis pertanyaannya sama namun dilakukan dengan kadar yang berbeda bergantung situasi dan kondisi informan.

Di samping pengamatan berperan serta, dan wawancara tidak berstruktur, peneliti dalam mengumpulkan data juga menggunakan dokumendokumen yang tersedia di lapangan atau perpustakaan-perpustakaan maupun dokumendukumen pribadi yang berhubungan dengan fokus penelitian ini.

\section{Profesionalisme Wartawan}

Sebelumnya menguraikan hasil penelitian, terlebih dahulu penulis akan menggambarkan profil informan karena menurut Creswell, penelitian dengan pendekatan kualitatif perlu dikemukakan gambaran umum tentang para informan yang dijadikan subjek penelitian (Creswell, 1988:147). Penulis mengambil 30 wartawan yang dijadikan informan. Jumlah informan tersebut melebihi saran Creswell yang mensyaratkan sebanyak delapan informan dalam penelitian kualitatif. Selain itu, mengingat dalam menguraikan profil informan berkaitan dengan persentase (\%) yang perlu diuraikan, penulis mengacu pendapat Ahmad Supandi yang mengatakan, $100 \%$ berarti seluruhnya, 90\%-99\% berarti hampir seluruhnya,
$60 \%-89 \%$ berarti sebagian besar, $51 \%-59 \%$ berarti lebih dari setengahnya, $50 \%$ berarti setengahnya, $40 \%-49 \%$ berarti hampir setengahnya, $10 \%-39 \%$ berarti sebagian kecil, $1 \%-9 \%$ berarti sedikit sekali, $0 \%$ berarti tidak sama sekali (Supandi, 1984: 52).

Sebagian besar informan berusia 31-40 tahun dan sebagian kecil berusia 20-30 tahun, sementara pendidikan informan hampir setengahnya sarjana (S1), dan sedikit sekali lulusan master (S2), sedangkan alamat kantor pusat informan sebagian besar di Kota Bandung, dan hanya sedikit sekali di Bogor. Guna mengetahui lebih lanjut profil informan ditinjau dari usia, pendidikan dan alamat kantor bisa dilihat dalam Tabel 1.

Sebagian besar informan bekerja di media massa cetak dan hanya sedikit sekali yang bekerja di media on-line. Jika dilihat dari kala penerbitan, setengahnya jumlah informan bekerja di media massa yang terbit harian dan hanya sedikit sekali yang bekerja di media massa yang terbit bulanan. Organisasi wartawan yang dimasuki informan hampir setengahnya menjadi anggota Persatuan Wartawan Indonesia (PWI), dan sedikit sekali menjadi anggota Aliansai Jurnalis Independen (AJI). Guna mengetahui lebih lanjut mengenai jenis media, kala penerbitan dan organisasi wartawan

Tabel 1

Usia, Pendidikan, dan Alamat Kantor Pusat

\begin{tabular}{|c|c|c|c|c|c|c|c|c|c|}
\hline \multirow[t]{2}{*}{ No. } & \multicolumn{3}{|c|}{ Usia (tahun) } & & \multicolumn{2}{|c|}{ Pendidikan } & \multicolumn{3}{|c|}{ Alamat Kantor Pusat } \\
\hline & Rentang & $\mathrm{Jml}$ & $\%$ & Jenjang & $\mathrm{Jlm}$ & $\%$ & Nama Kota & $\mathrm{JIm}$ & $\%$ \\
\hline 1. & $20-30$ & 2 & 6,67 & $\mathrm{~S} 2$ & 1 & 3,33 & Bandung & 18 & 60 \\
\hline 2. & $31-40$ & 16 & 53,33 & $\mathrm{~S} 1$ & 13 & 43,33 & Jakarta & 6 & 20 \\
\hline 3. & $41-50$ & 9 & 30 & D1-D3 & 6 & 20 & Medan & 4 & 13,33 \\
\hline \multirow[t]{2}{*}{4.} & $<50$ & 3 & 10 & SMA & 10 & 33,33 & Bogor & 2 & 6,77 \\
\hline & Jumlah & 30 & 100 & Jumlah & 30 & 100 & Jumlah & 30 & 100 \\
\hline
\end{tabular}

Sumber: Wawancara dengan Informan

Tabel 2

Jenis Media, Kala Penerbitan, dan Organisasi

\begin{tabular}{|c|c|c|c|c|c|c|c|c|c|}
\hline \multirow[t]{2}{*}{ No. } & \multicolumn{3}{|c|}{ Jenis Media } & \multicolumn{3}{|c|}{ Kala Penerbitan } & \multicolumn{3}{|c|}{ Organisasi } \\
\hline & Nama & $\mathrm{Jml}$ & $\%$ & Nama & $\mathrm{Jlm}$ & $\%$ & Nama & $\mathrm{Jlm}$ & $\%$ \\
\hline 1. & Cetak & 20 & 66,67 & Harian & 15 & 50 & PWI & 14 & 46,67 \\
\hline 2. & Radio & 4 & 13,33 & Mingguan & 3 & 10 & AJI & 2 & 6,77 \\
\hline 3. & TV & 4 & 13,33 & Bulanan & 2 & 6,67 & IJTI & 4 & 13,33 \\
\hline 4. & On Line & 2 & 6,67 & Setiap Saat & 10 & 33,33 & $\begin{array}{l}\text { Non } \\
\text { Org. }\end{array}$ & 10 & 33,33 \\
\hline Jumlah & & 30 & 100 & Jumlah & 30 & 100 & Jumlał & 30 & 100 \\
\hline
\end{tabular}


yang diikuti dapat dijelaskan oleh Tabel 2 .

Hampir setengahnya informan tidak memiliki kelompok kerja (Pokja) tersendiri, dan sedikit sekali informan bertugas untuk meliput bidang Telkom sekaligus tercatat sebagai Pokja Telkom. Penghasilan informan sangat beragam, setengahnya jumlah informan berpenghasilan tidak menentu, dan sebagian kecil informan memiliki gaji lebih besar dari upah minimum regional (UMR) Kota Bandung, sebagian kecil lagi memiliki gaji lebih kecil dari UMR. Namun demikian, hampir setengahnya informan tidak memiliki pekerjaan sampingan selain menjadi wartawan, dan hampir setengahnya memiliki pekerjaan samping selain menjadi wartawan, yaitu bisnis. Guna mengetahui lebih lanjut mengenai Pokja, penghasilan, dan pekerjaan sampingan bisa dilihat dalam Tabel 3.

Melalui wawancara mendalam dan pengamatan berperan serta kepada 30 wartawan di Kota Bandung yang dijadikan informan, memberikan gambaran bahwa wartawan profesional adalah wartawan yang bekerja sesuai dengan keahlian atau profesinya dengan menjungjung tinggi KEWI maupun aturan yang mengatur gerak langkahnya saat melakukan kegiatan kejurnalistikan. Selain itu, wartawan profesional adalah wartawan yang bertanggung jawab, memiliki komitmen, jujur, konsekuen, memiliki kemampuan menulis sesuai kode etik wartawan Indonesia. Wartawan profesional adalah mereka yang mampu bekerja sesuai dengan bidangnya, bekerja dengan baik sebagai wartawan, bekerja secara cerdas bagi masyarakat dan mengagumkan. Masih banyak ungkapan lain yang disampaikan para informan mengenai pemaknaan wartawan profesional. Penulis mengkonstruksi ungkapan-ungkapan para informan ke dalam empat kategori atau empat varian profesionalisme. Keempat varian yang akan diuraikan satu per satu tersebut adalah otonomi, komitmen, tanggung jawab dan keahlian.

\section{Otonomi}

Profesionalisme dalam pandangan informan, merupakan kemandirian dari seorang wartawan yang tidak boleh diganggu gugat oleh siapa pun. Kemandirian ini diidentikkan dengan otonomi. Kemandirian atau otonomi seorang wartawan saat melaksanakan tugas kejurnalistikanya harus dimiliki sehingga wartawan bisa mendapatkan dan mengolah infomasi yang didapat dari lapangan dengan leluasa tanpa ada campur tangan siapapun, termasuk dari redaksi sebab saat di lapangan meliput sebuah karya jurnalistik, wawancara maupun menciptakan berita redaksi tidak tahu menahu secara detil. Artinya redaksi hanya memberikan penugasan secara garis besar sedangkan teknik di lapangan agar bisa mendapatkan bahan tulisan, lalu dibuat menjadi sebuah karya jurnalistik sepenuhnya berada ditangan wartawan. Selain itu kemandirian wartawan sama halnya dengan otonomi yang dimiliki profesi lainnya, yakni kebebasan untuk mendapatkan informasi sebanyak-banyaknya dari narasumber karena wartawan adalah wakil rakyat dan informasi yang dikemas wartawan lalu menjelma menjadi sebuah karya jurnalistik tiada lain ditujukan untuk kepentingan masyarakat.

Pandangan informan mengenai kemandirian atau otonomi wartawan tersebut nampaknya sejalan dengan pendapat Rosihan Anwar (1977), Amar (1984), dan Masduki (2004). Pandangan para informan mengisyaratkan adanya kebebasan wartawan dalam melaksanakan pertimbangan sendiri yang oleh Rosihan Anwar, Amar dan Masduki disebut sebagai salah satu unsur atau atribut yang melekat dalam profesionalisme seorang wartawan. Amar (1984) menyatakan, jurnalis yang baik tidak perlu diperintahkan oleh siapa pun juga, ide dan semangatnya selalu melahirkan berita dan laporan yang menggugah sanubari pembacanya.

Tabel 3

Kelompok Kerja yang Diikuti, Penghasilan, Pekerjaan Sampingan

\begin{tabular}{|c|c|c|c|c|c|c|c|c|c|}
\hline \multirow[t]{2}{*}{ No. } & \multicolumn{3}{|c|}{ Kelompok Kerja yang Diikuti } & \multicolumn{3}{|c|}{ Penghasilan Profesi Wartawan } & \multicolumn{3}{|c|}{ Pekerjaan Sampingan } \\
\hline & Nama & $\mathrm{Jml}$ & $\%$ & Nama & Jlm & $\%$ & Nama & $\mathrm{JIm}$ & $\%$ \\
\hline 1. & Gedung Sate & 3 & 10 & $<$ dari UMR & 4 & 13,33 & Bisnis & 12 & 40 \\
\hline 2. & Pemkot & 6 & 20 & > dari UMR & 11 & 36,67 & Ngajar & 2 & 6,67 \\
\hline 3. & Telkom & 2 & 6,67 & Tidak tentu & 15 & 50 & Koperasi & 1 & 3,33 \\
\hline 4. & Transportasi & 4 & 13,33 & - & - & & Tidak ada & 15 & 50 \\
\hline 5. & Kejakimpol & 3 & 10 & - & - & - & - & & \\
\hline 6. & Non. Pokja & 12 & 40 & - & - & - & - & & \\
\hline Jum & & 30 & 100 & Jumlah & 30 & 100 & Jumlah & 30 & 100 \\
\hline
\end{tabular}


Namun, dalam prakteknya di lapangan, otonomi wartawan tidak bisa sepenuhnya dilaksanakan karena banyak aspek yang mewarnai saat wartawan hendak meraih dan menegakkan otonomi. Aspek-aspek tersebut adalah (1) Kebijakan tempat bekerja; (2) Narasumber; (3) Masyarakat; dan (4) Keluarga terutama berkaitan dengan pemenuhan kebutuhan ekonomi.

\section{Komitmen}

Menurut informan, profesionalisme adalah adanya kehendak yang menitikberatkan kepada pelayanan untuk masyarakat dalam bentuk penyebaran karya jurnalistik melalui media massa seperti surat kabar, majalah, radio dan televisi yang menjadi tempat kerjanya. Artinya, bukan pemenuhan untuk mendapatkan keuntungan ekonomi pribadi karena eksistensi wartawan sebagai pelayan kepada masyarakat. Jika ada berita yang diperkirakan akan menjadi perhatian masyarakat banyak harus segera diberitakan karena akan memberikan manfaat bagi masyarakat banyak. Karena itulah, kehendak yang tertanam dalam hati seorang wartawan lalu membentuk sebuah komitmen harus tampak dalam setiap kegiatan kejurnalistikan di lapangan.

Pandangan informan tersebut nampaknya sejalan dengan pendapat yang disampaikan Rosihan Anwar (1977) yang didikung oleh pandangan McQuail (1986), dan Masduki (2004). Rosihan Anwar berpendapat, komitmen wartawan yaitu menitikberatkan dalam soal pelayanan dan bukan dalam soal keuntungan ekonomi pribadi. Apa yang disampaikan oleh Rosihan Anwar tersebut, mengisyaratkan bahwa secara teknis di lapangan, wartawan saat bertugas harus menomorsatukan pelayanan bukan untuk mencari keuntungan secara pribadi.

Namun secara teknis di lapangan, tidak semudah apa yang diucapkan sama seperti hendak meraih dan menegakkan kemandirian atau otonomi. Dalam meraih dan menegakkan komitmen pun banyak aspek yan mewarnainya. Aspek-aspek yang mewarnai upaya meraih dan menegakkan otonomi wartawan, juga ditemukan dalam upaya meraih dan menegakkan komitmen oleh wartawan. Aspek-aspek tersebut adalah (1) Kebijakan tempat bekerja; (2) Narasumber; (3) Masyarakat; dan (4) Keluarga terutama berkaitan dengan pemenuhan kebutuhan ekonomi.

Kebijakan tempat berkerja-Kemandirian atau otonomi wartawan tidak bisa secara mutlak dilaksanakan oleh wartawan, sebab saat wartawan menjalankan tugasnya tidak terlepas atau bahkan harus berpedoman dan memenuhi kebijakan tempat bekerja, seperti redaksi karena wartawan berada di bawah redaksi. Jadi, apa yang ditugaskan pemimpin redaksi melalui redaktur atau koordinator liputan merupakan kewajiban yang harus dilaksanakan termasuk melaksanakan kebijakan redaksi yang memberlakukan bahwa setiap berita yang dimuat harus prospektif untuk bisa menjaring iklan atau meningkatkan jumlah oplah, ataupun langganan. Karena itulah dalam menulis sebuah karya jurnalistik pun seorang wartawan harus mampu "bermain cantik" dalam menggunakan bahasa yang lebih menarik dalam upaya memenuhi penugasan dari redaksi terutama yang berkaitan dengan pembuatan karya jurnalistik yang mengarah ke dalam upaya menjaring iklan dan meningkatkan tiras.

Selain itu, Kinerja media massa terselenggara dalam beragam kepentingan bukan hanya satu kepentingan saja. Meskipun dalam kadar yang sangat kecil, bisa saja kemandirian atau otonomi wartawan masih dimiliki wartawan mulai dari kepekaan terhadap lingkungan, penyikapan sebuah berita maupun pengembangan wawancara. Artinya, ketika melaksanakan pengembangan wawancara dengan narasumber guna mendapatkan informasi yang lebih dalam adalah kreativitas wartawan itu sendiri sebab meskipun pihak redaksi melalui redaktur atau koordinator reporter sudah memberikan kisi-kisi pertanyaan, tetapi biasanya kisi-kisi pertanyaan tersebut berkembang menjadi anak beranak pertanyaan yang disampaikan wartawan kepada narasumber tanpa harus diperintah redaksi melalui redaktur maupun koordinator liputan. Namun disisi lainnya, dalam kadar yang lebih besar lagi kebijakan tempat bekerja turut mewarnai kadar kemandirian atau otonomi si wartawan dalam melaksanakan tugasnya. Begitu juga saat meraih dan berusaha menegakkan komitmen wartawan diwarnai oleh kebijakan tempat bekerja.

Saat wartawan hendak mencoba memenuhi dan menyuarakan kepentingan masyarakat dan mengambaikan kepentingan yang lainnya sulit terpenuhi sebab wartawan memiliki atasan yang lebih tinggi lagi yaitu asisten redaktur, redaktur, redaktur pelaksana, dan pemimpin redaksi. Bisa saja wartawan setelah memeroleh data maupun wawancara atau laporan padangan mata yang dianggap akan menyuarakan keinginan dan kebutuhan masyarakat dimuat oleh surat kabarnya, tetapi jika kebijakan perusahaan yang diwakili pemimpin redaksi tidak menghendaki maka keinginan wartawan tersebut tidak akan pernah terwujud. Apa yang dikehendaki wartawan belum tentu dikehendaki pemimpin redaksi. Wartawan menemui kekecewaan karena pihak redaksi banyak yang tidak mengerti atau pura-pura tidak mengerti terhadap komitmen yang dimiliki wartawan.

Bagi media cetak yang kala terbitnya mingguan-dwimingguan-bulanan, terutama untuk tabloid dan majalah, kebergantungan melaksanakan tugas-tugas redaksional ini semakin 
tampak jika dibandingkan dengan surat kabar harian karena bentuk pemberitaan yang dibutuhkan bukan penerbitan harian adalah pendalaman materi.

Narasumber-Penegakan otonomi oleh wartawan juga diwarnai narasumber. Narasumber bersentuhan langsung dengan wartawan yang bakal menulis sebuah karya jurnalistik, sedangkan redaksi hanya menentukan untuk memuat atau tidaknya sebuah karya jurnalistik yang dibuat wartawan. Keinginan narasumber perlu mendapat perhatian yang proporsional untuk dijadikan referensi dalam membuat sebuah karya jurnalistik tanpa mengesampingkan fakta dan data. Narsumber juga memiliki posisi yang sangat penting dalam mewarnai upaya meraih dan menegakkan komitmen seorang wartawan sebab semua karya jurnalistik berasal dari narasumber sedangkan pelayanan kepada masyarakat dalam bentuk pemenuhan kebutuhan dan keinginan masyarakat merupakan efek dari informasi yang diberikan narasumber tersebut. Jadi dari mana wartawan akan memberikan pelayanan kepada masyarakat dan mengabaikan keuntungan secara pribadi jika tidak ada narasumber yang mau memberikan infomasi bagi masyarakat.

Masyarakat memiliki posisi yang sangat kuat dalam mewarnai penegakan otonomi wartawan karena eksistensi wartawan menyuarakan kepentingan masyarakat, oleh karena itu berbagai pertimbangan di luar kepentingan masyarakat harus disisihkan. Kepentingan masyarakat berupa suara-suara yang menyangkut kebutuhan dan keinginan masyarakat perlu diakomodir wartawan semaksimal mungkin.

Yang paling utama adalah otonomi wartawan perlu diarahkan kepada kepentingan masyarakat Penegakan komitmen wartawan juga diwarnai oleh masyarakat sebab wartawan hanya berperan sebagai pelaksana keinginan dan kebutuhan masyarakat dengan demikian komitmen wartawan sulit dibangun jika mengabaikan kepentingan masyarakat.

Keluarga-Aspek keluarga juga tidak ketinggalan ikut mewarnai penegakan otonomi dan komitmen, terutama yang berkaitan dengan pemenuhan kebutuhan ekonomi keluarga. Kepentingan pemenuhan kebutuhan ekonomi keluarga perlu dipertimbangkan dalam menegakkan otonomi seorang wartawan. Wartawan profesional gajinya besar sehingga dia bisa menghidupi diri sendiri dan keluarganya secara memadai dan dia bisa bekerja independen. Mempertimbangkan faktor keluarga berarti wartawan akan mencari surat kabar yang mampu memberikan gaji yang besar sehingga dia tenang dalam bekerja menjadi wartawan, tetapi jika tidak didapat maka akan melakukan perbuatanperbuatan yang kurang terpuji sebagai wartawan.
Begitu juga dalam meraih dan menegakkan komitmen wartawan diwarnai oleh aspek keluarga terutama berkaitan dengan pemenuhuan kebutuhan keluarga. Keluarga menuntut pemenuhan kebutuhan secara finansial. Biasanya wartawan juga tidak tenang jika kebutuhan secara finansial keluarganya belum terpenuhi. Karena itulah dalam upaya memenuhi kebutuhan ekonomi keluarga, tugas wartawan untuk menyuarakan kebutuhan dan keinginan masyarakat sering terabaikan, dan yang muncul adalah bagaimana mendapatkan sejumlah finansial untuk memenuhi kebutuhan hidupnya. Apalagi jika perusahaan penerbitannya belum memberikan gaji yang layak. Memang tidak bisa menutup mata bahwa begitu banyak bermunculan media yang hanya ditopang pendanaan dari hasil jerih-payah wartawannya di lapangan. Jangankan untuk memberi gaji atau upah bagi wartawan, bahkan sebaliknya wartawan dituntut memberikan kontribusi bagi biaya cetak edisi berikutnya dari media bersangkutan. Wartawan memang perlu memiliki komitmen dengan memberikan pelayanan kepada masyarakat, tetapi pelayanan tersebut harus bisa saling menguntungkan baik bagi si wartawan sebagai individu yang punya keluarga maupun bagi perusahaan tempatnya menggantungkan hidup.

\section{Tanggung Jawab}

Dalam pandangan para informan, wartawan yang profesional selain memiliki kemandirian atau otonomi, memiliki tekad yang kuat dan membentuk sebuah komitmen, juga perlu memiliki kemampuan memenuhi kewajiban sebagai wartawan yakni mencari, mengolah, membuat berita sesuai dengan ketentuan-ketentuan yang ditetapkan. Perkataan lain, wartawan profesional memiliki tanggung jawab atas pekerjaannya bukan dilandasi keinginan pihak luar melainkan menjalankan suatu pekerjaan karena didasari untuk memenuhi kewajibannya sebagai seorang wartawan. Selain itu tanggung jawab wartawan adalah sebuah konsekuensi yang harus diterima wartawan. Artinya, wartawan tidak perlu melupakan semua kegiatannya, tetapi harus benarbenar meresapinya, sehingga kegiatan yang dilakukan oleh wartawan tersebut menjadi sebuah konsekuensi yang harus ditanggung wartawan bersangkutan.

Pendapat yang disampaikan informan, didukung Rosihan Anwar (1977), McQuail (1986), Ashadi Siregar (1995) dan Masduki (2004) yang berpendapat, tanggung jawab wartawan adalah kemampuan memenuhi kewajiban-kewajiban atau bertindak tanpa kewibawaan penuntutan dari atasan, penciptaam serta penerapan kode etik.

Pelaksanaan tanggung jawab wartawan tidaklah mudah sebab saat wartawan hendak melaksanakan atau meraih tanggung jawabnya 
harus bersentuhan dengan aspek-aspek lain yang turut mewarnai dalam upaya melaksanakan atau meraih tanggung jawab wartawan. Aspek-aspek tersebut selain kebijakan tempat bekerja, juga ada tiga aspek lainnya yaitu (1) Kode etik wartawan Indonesia (KEWI); (2) Pertimbangan pribadi/hati nurani sendiri; dan (3) Rekan satu profesi.

Kebijakan tempat bekerja-Dalam melaksanakan tugas kewartawanan termasuk tugas penting dari kantor redaksi, wartawan diwajibkan menaati kebijakan tempatnya bekerja khususnya redaksi. Mengingat dunia jurnalistik adalah kerja kolektif maka semua menjadi tanggung jawab bersama. Sebelum berita diturunkan, tentunya dirapatkan dahulu dengan redaksi sehingga redaksi tahu pasti akibatnya bila sebuah berita dimuat. Wartawan sekadar mencari berita yang benar, sedangkan risiko harus ditanggung bersama. Bisa dimuat atau tidaknya berita bergantung kebijakan redaksi, dengan demikian tanggung jawab berada di lembaga pers bersangkutan. Berita diterbitkan berdasarkan pertimbangan lembaga, sehingga walau harus menciptakan pers yang bebas dan bertanggung jawab tetapi terlalu riskan jika wartawan harus bertanggung jawab secara pribadi. Menanti KEWI-Tanggung jawab wartawan sudah diatur dalam KEWI. Bila melanggar, konsekuensinya jeratan hukum. KEWI merupakan ikrar yang dibuat wartawan sehingga harus ditaati pula oleh wartawan sebagai ungkapan tanggung jawab wartawan dalam menjalankan profesinya. Jadi, alangkah tidak konsekuennya jika wartawan tidak mengacu kepada KEWI.

KEWI dan UU. No. 40 tahun 1999 merupakan koridor yang harus ditaati setiap wartawan, sehingga bisa mengungkapkan mana yang baik dan mana yang tidak, mana yang boleh dilakukan wartawan dan mana yang tidak. Adanya KEWI dan UU. No. 40 tahun 1999 merupakan realisasi tanggung jawab wartawan terhadap profesinya. Pertimbangan nurani pribadi mewarnai penegakan tangung jawab wartawan, sebab karya jurnalistik yang ditulis seorang wartawan juga merupakan tanggung jawab wartawan secara pribadi. Dengan demikian pertimbangan secara pribadi atas sebuah karya jurnalistik yang dibuatnya merupakan sesuatu perbuatan yang penting dan utama. Rekan sejawat bagi wartawan kadangkadang memiliki keterbatasan meliput pemberitaan yang begitu banyak. Karenanya, tidak jarang di antara mereka "berbagi tugas," sehingga tidak ada peristiwa atau bahan berita yang luput untuk diberitakan. Sebuah berita untuk disiarkan, tanggungjawabnya besar, karena itu jika hasil liputan sendiri pertanggungjawabannya bisa dijamin, tetapi kalau dibuat wartawan lain tetap harus berupaya melakukan check and recheck. Untuk itu, harus punya rekan yang benar-benar bisa dipercaya. Bila dia sendiri yang melakukannya akan kewalahan, apalagi bila ada liputan-liputan lain di luar Kota Bandung yang membutuhkan kehadirannya. Alhasil, bila terjadi berita bentrok maka dia akan berbagi tugas liputan dengan rekanrekannya, dengan demikian terjadi barter berita.

\section{Keahlian}

Profesionalisme dalam pandangan informan, selain memiliki kemandirian atau otonomi, tekad yang kuat dan mampu membentuk sebuah komitmen yang jelas, lalu ditopang dengan ikut bertanggung jawab, juga perlu adanya kepandaian lain daripada yang lain sehingga seorang wartawan benar-benar mahir atau ahli dalam bidangnya. Mahir atau keahlian adalah semacam keterampilan yang dimiliki oleh wartawan dalam bidang mencari, mengolah, dan menyajikan berita yang siap disebarkan kepada masyarakat, dan untuk mendapatkannya tidak begitu saja melainkan adanya usaha dari wartawan bersangkutan sehingga benar-benar mahir dalam dunianya. Pandangan para informan tersebut sejalan dengan pendapat McQuail (1986), Ashadi Siregar (1995) dan Masduki (2005). Intinya McQuail, Ashadi Siregar, dan Masduki berpendapat, keahlian adalah menjalankan suatu jasa yang unik dan esensial dengan titik berat tertuju kepada intelektual, periode yang panjang daripada latihan khusus supaya memeroleh pengetahuan yang sistematik.

Diperolehnya keahlian wartawan, bukan hanya secara formal semata, juga bisa didapat secara informal, namun yang penting adalah bagaimana wartawan memiliki ilmu kewartawanannya yang siap dipakai di lapangan. Oleh karenanya, dalam upaya meraih keahlian wartawan ada empat aspek yang tidak bisa diabaikan begitu saja. Keempat aspek tersebut adalah (1) Ilmu jurnalistik; (2) Ilmu Nonjurnalistik; (3) Gabungan antara ilmu jurnalistik dan non jurnalistik; (4) Ilmu di luar tugas keredaksian.

Ilmu Jurnalistik sangat diperlukan seorang wartawan dalam memeroleh keahlian, karena bisa membawa wartawan bertindak sesuai dengan pengetahuan dan kemampuan sebagai wartawan. Sehingga unsur-unsur negatif dalam dunia kewartawanan bisa terhidar karena sudah mendapatkan bimbingan ketika mereka kuliah. Artinya, wartawan bisa memfokuskan diri hanya kepada pekerjaannya yang sesuai dengan pendidikan yang dimilikinya. Pendidikan dimaksud menyangkut kepada penempuhan pendidikan kejurnalistikan di institusi pendidikan formal seperti universitas maupun lembaga pendidikan lainnya seperti kursus singkat. Ilmu nonjurnalistik-Ilmu jurnalistik bukan satu satunya ilmu yang bisa mengantarkan seseorang menjadi wartawan, disiplin nonjurnalistik pun turut mewarnai keahlian seorang wartawan. Artinya, wartawan tidak bisa 
menutup mata, bahwa kini banyak wartawan yang bukan berasal dari latar belakang pendidikan berbasis tulis-menulis yang ternyata berhasil sebagai wartawan, bahkan pendidikan yang diampunya ketika kuliah memberikan kontribusi dalam mempercepat pemahaman tentang dunia wartawan. Misalnya, ketika seorang wartawan duduk dibangku kuliah mengambil jurusan ekonomi maka ketika berhadapan dengan tugas untuk meliput berita ekonomi tampak tidak mengalami kesulitan.

Gabungan antara ilmu jurnalistik dengan ilmu nonjurnalistik-Wartawan yang benar-benar memiliki keahlian lengkap karena diwarnai atau dibekali ilmu jurnalistik sekaligus dibekali ilmu lain yang sangat menunjang dalam menjalankan profesinya sebagai wartawan. Perkataan lain, keahlian seorang wartawan akan lebih lengkap jika ditunjang pendidikan jurnalistik sekaligus ditunjang ilmu bidang lainnya. Dalam kondisi tertentu wartawan perlu memiliki pengetahuan di luar jurnalistik, karena ilmu jurnalistik diarahkan hanya satu bidang kejurnalistikan semata. Memang akan lebih bagus jika seorang wartawan mengetahui tentang dunia komunikasi agar mengetahui ramburambu di dunia kewartawanan. Wartawan lebih baik menjalankan profesinya berdasarkan keterampilan yang berbasis pengetahuan sistemik sehingga mendapatkan ilmu bidang lainnya, tidak akan menemui kesulitan mendapatkan bahan berita, karena sudah mendapatkan bekal ilmunya.

Meskipun demikian, pengetahuan jurnalistik pun sudah dipegang sebelumnya. Pendidikan yang diperoleh sebelumnya bisa mewarnai saat wartawan melakukan tugas jurnalistik, tetapi sebetulnya sangat bergantung pula kepada aplikasinya di lapangan. Dalam melaksanakan pekerjaannya sudah menjadi kewajiban seorang jurnalis untuk menggali semua keilmuan, sebagai alat penunjang dan bahan referensi. Ilmu di luar tugas keredaksian-IImu-ilmu di luar keredaksian ternyata memiliki kontribusi dalam kehidupan media massa terutama bagi media-media tertentu. Ilmu-ilmu di luar tugas keredaksian tersebut adalah seperti ilmu tentang bagaimana mendapatkan iklan yang banyak dan bagaimana memasarkan media massa. Soal keahlian, bila dalam melaksanakan pekerjaannya seorang wartawan berdisiplin jurnalistik maupun ilmu-ilmu pengetahuan di luar tugas keredaksian adalah satu poin penting sebab kehidupan jurnalistik saat ini bukan ilmu teori tentang menulis berita saja tetapi dunia jurnalistik adalah dunia industri. Sebagus dan semenarik apa pun sebuah karya jurnalistik tetapi tanpa penyebaran oleh tangan-tangan industri, akan memeroleh penyebaran yang terbatas. Di sisi lain, bagi media massa yang belum bonafid, tidak sekadar memerlukan kehadiran para wartawan yang bisa menulis berita, tetapi yang utama adalah bagaimana wartawan bisa berkontribusi dari segi finansial demi keberlanjutan lembaga media massanya. Soal berita yang berimbang atau parameter kaidah jurnalistiknya, itu bisa diatur oleh redaktur yang sengaja diberi honorarium. Bila dalam melaksanakan pekerjaannya seorang wartawan memiliki disiplin jurnalistik maupun ilmu di luar tugas redaksi merupakan nilai tambah yang positif.

\section{Simpulan dan Saran}

Hasil penelitian ini menunjukkan, profesionalisme dalam pandangan wartawan Kota Bandung bisa dibagi dalam empat kategori, yaitu otonomi, komitmen, tanggung jawab dan keahlian.

Secara teknis di lapangan wartawan sulit menegakkan otonomi maupun komitmen karena ada beberapa aspek yang turut serta mewarnai upaya meraih dan menegakkan otonomi maupun komitmen. Aspek-aspek tersebut adalah Kebijakan tempat bekerja, Narasumber, Masyarakat, Keluarga. Dalam meraih dan menegakkan tanggung jawab wartawan di Kota Bandung pun mengalami kesulitan karena ada beberapa aspek yang turut serta mewarnai dalam upaya meraih dan menegakkan tanggung jawab tersebut. Aspekaspek tersebut adalah Kebijakan tempat bekerja; Kode Etika Wartawan Indonesia; Pertimbangan Pribadi (hati nurani); Teman sejawat.

Aspek-aspek yang mewarnai upaya meraih dan menegakkan keahlian wartawan adalah disiplin Ilmu Jurnalistik; IImu nonjurnalistik; Gabungan antara IImu jurnalistik dan Ilmu nonjurnalistik; Ilmu di luar tugas jurnalistik.

Penulis menyarankan, untuk memeroleh gambaran secara umum mengenai profesionalisme wartawan diperlukan penelitian lanjutan dengan memperluas fokus pengamatan tidak hanya wartawan di Kota Bandung, melainkan wartawan di Kabupaten Bandung, Kota Cimahi dan Kabupaten Bandung Barat serta wilayah yang lebih besar lagi, dengan menggunakan pendekatan subjektif.

Mengingat masih munculnya penyeragaman pandangan negatif terhadap wartawan di Kota Bandung, maka perlu diadakan penelitian lebih lanjut soal idealisme wartawan di Kota Bandung, dengan pendekatan subjektif.

\section{Daftar Pustaka}

Allport, G. (1954) Nature of Prejudice, Addison Wesley Publishing Company, Inc, US

Amar, Djen, M., (1984) Hukum Komunikasi Jurnalistik, Alumni, Bandung

Anwar, Rosihan. (1977) Profil Wartawan Indonesia, Departemen Penerangan RI, Jakarta

Assegaff, Djafar, Husin. (1992) Jurnalistik Massa Kini, Ghalia, Jakarta 
Astraatmadja, Atmakusumah dan Luwarso, Lukas. (2001). Menegakkan Etika Pers. Jakarta: Dewan Pers

Creswell. John. W. (1998). Qualitatif Inqury and Research Design Choosing Among Five Traditions. Thousand Oaks: sage Publication

Garna, H. Judistira K. (1999). Metode Penelitian: Pendekatan Kualitatif, CV. Primaco Akademica, Bandung

Goffman, Erving. (1959). The Presentation of Self In Everyday Life, Penguin Book, Cox \& Wyman Ltd, reat Britain

Hester, Albert L, Way Lan J To. (1987). Handbook for Third World Journalist, The University of Georgia, Athens

Johnson, Paul, Doyle. (1986). Teori Sosiologi Klasik dan Modern, Gramedia, Jakarta

Lincoln, Yvonna S \& Egon G Guba. (1985). Naturalistic Inquiry, Sage Publication Baverly Hills

Lindolf, Thomas., R, (1995). Qualitative Communications Research Methods, Sage Publications, California, USA

Lubis, Mochtar. (1985). Manusia Indonesia Sebuah Pertanggungjawaban, Midas Surya Grafindo, Jakarta

Masduki, (2004), Profesionalisme Wartawan, Alumni, Bandung

McQuail, Denis. (1991). Teori Komunikasi Massa. Suatu Pengantar, Erlangga, Jakarta.

Miles, Mathew \& A Michael Huberman. (1990). Qualitative Data Analysis, Sage Publications Inc

Mimbar, Vol. XXII, No. 1 (Januari-Maret 2006): 5292 "Terakreditasi" SK Dikti No. 64a/DIKTI/Kep/ 241

Mimbar. Vol.XXVII, No.1 (Juni 2011): 1-10 "Terakreditasi" SK Dikti No. 64a/DIKTI/Kep/ 241

Moleong, Lexy J. (1989). Metode Penelitian Kualitatif, Remaja Karya, Bandung

Muhadjir. (1987). Evaluasi dan Strategi Kebudayaan, Fakultas Sastra Universitas Indonesia, Depok

Mulyana, Deddy. (1989). Komunikasi Antar Budaya, PT Remaja Rosdakarya, Bandung

Mulyana, Deddy. (2001). Metode Penelitian Kualitatif, Paradigma Baru Komunikasi dan Ilmu Sosial Lainnya, Rosdakarya, Bandung

Mulyana, Deddy. (2004). Komunikasi Efektif, Suatu
Pendekatan Lintasbudaya, Remaja Rosdakarya, Bandung

Nasution, Andi. (1996). Metode Penelitian Naturalistik, Tarsito, Bandung

Oetama, Jakob. (1987). Perspektif Pers Indonesia, LP3S, Jakarta

Peraturan Rumah Tangga Persatuan Wartawan Indonesia

Pramudya, Willy (editor). (2000). Enam Tahun AJI, Aliansi Jurnalistik Indonesia, Jakarta

Purwasito, (2003). Komunikasi Multikultural, Univesritas Muhamadiyah, Surakarta

Qodari, Barni, (1999) Pers dan Kehidupan Sosial, Jakarta

Schutz, Alfred, (1972) The Phenomenology of the Social World, Heinemann Educational Books, London

Sendjaja, S., Djuarsa. (1993) Ekologi Media: Analisa dan Aplikasi Teori: niche dalam Penelitian Tentang Kompetisi antar Industri Media, dalam Jurnal Kumunikasi Audentia Vol. 1/no. 2 April-Juni 2003, Hal: 118-128

Semi, Atar, M. (1995). Teknik Penulisan Berita, Features, dan Artikel, Mugantara, Bandung

Siregar, Ashadi. (1985). Profesi Wartawan di Mata Saya, Hanindita Offset, Yogyakarta

Sterentz, Herbert. (1993). Reporter dan Sumber Berita, Persekongkolan dalam Mengemas dan Menyesatkan Berita, Gramedia Pustaka Utama, Jakarta

Supandi, Ahmad, (1984). Metode Penelitian Sosial, Alumni, Bandung

Undang-undang No. 40 tahun 1999, tetang Pers.

Veeger, K., J. (1984). Realitas Sosial Refleksi Filsafat Sosial Atas Hubungan Individu - Masyarakat dalam Cakrawala Sejarah Sosiologi, Gramedia Pustaka Utama, Jakarta

Wright, Charles Robert. (1975). Mass Communication: A Sociological Perspentive, Random Hous Inc

Yin, K., Robert. (1997). Studi Kasus Desain dan Metode, Raja Grafindo Persada, Jakarta 